Jurnal IImiah Potensia, 2019, Vol. 4 (2), 78-86

https://ejournal.unib.ac.id/index.php/potensia

e-issn: 2621-2382 p-issn: 2527-9270

\title{
Pengaruh Kreasi Kertas Kokoru Terhadap Perkembangan Kreativitas Anak Di Taman Kanak- Kanak Nurul Yakin Ringan-Ringan Kabupaten Padang Pariaman
}

\author{
Mia Amalia ${ }^{1}$ \\ amalia12mia@gmail.com
}

\section{Rismareni Pransiska²}

Yulsyofriend ${ }^{3}$

1, 2, 3 Program Studi Pendidikan Guru Pendidikan Anak Usia Dini, Universitas Negeri Padang

Received: November $29^{\text {th }} 2018$

Accepted: July $4^{\text {th }} 2019$

Published: July $21^{\text {st }} 2019$

\begin{abstract}
Penelitian ini bertujuan untuk mengetahui pengaruh kreasi kertas kokoru terhadap perkembangan kreativitas anak. Penelitian ini menggunakan pendekatan kuantitatif yang berbentuk quasy eksperimen. Berdasarkan analisis data, diperoleh rata-rata hasil tes kelas eksperimen adalah 80 sedangkan kelas kontrol 73,75. Berdasarkan perhitungan t-tes diperoleh thitung lebih besar dari tabel menunjukan bahwa terdapat perbedaan signifikan antara kedua kelas tersebut. Maka dapat disimpulkan bahwa kreasi kertas kokoru berpengaruh terhadap perkembangan kreativitas anak di taman Kanak-kanak Nurul Yakin Ringan-ringan Kabupaten Padang Pariaman tahun ajaran 2018/2019.
\end{abstract}

Keywords: Kreasi Kertas Kokoru. Perkembangan Kreativitas

How to cite this article:

Amalia, M., Pransiska, R., \& Yulsofriend, Y. (2019). Pengaruh Kreasi Kertas Kokoru Terhadap Perkembangan Kreativitas Anak Di Taman Kanak-Kanak Nurul Yakin Ringan-Ringan Kabupaten Padang Pariaman. Jurnal IImiah POTENSIA, 4(2), 78-86. https://doi.org/10.33369/JIP.4.2.78-86

\section{PENDAHULUAN}

Kreativitas merupakan sifat pribadi seorang individu yang tercermin dari kemampuannya untuk menciptakan sesuatu yang baru. Biasanya seorang individu yang kreatif memiliki sifat mandiri. Kreativitas seni merupakan bagian dari kegiatan berproduksi atau berkarya dapat berupa hasil karya seni yang mempunyai nilai unik, indah dan kesan lainnya. Berdasarkan kurikulum 2013 PAUD bahwa anak usia 5-6 tahun mengalami pertumbuhan dan perkembangan menyelesaikan masalah sehari-hari secara kreatif, mengenal dan menunjukkan berbagai karya dan aktivitas seni dengan menggunakan berbagai media.

Berdasarkan observasi awal, permasalahan kreativitas yang terjadi di TK
Nurul Yakin Ringan-ringan Kabupaten Padang Pariaman adalah media yang di gunakan dalam kegiatan pembelajaran kurang berpengaruh dalam merangsang dan menstimulasi perkembangan kreativitas anak, pembelajaran hanya terfokus pada penggunaan krayon dan dan majalah saja, pada hal dalam pengembangan kreativitas anak banyak media yang bisa dimanfaatkan. Media serta bahan-bahan yang digunakan dalam mengembangkan kreativitas anak kurang bervariatif dan membosankan serta membuat anak menjadi kurang kreatif dalam memanfaatkan benda-benda yang ada disekitarnya. Serta minimnya ide-ide kreativitas dari anak dalam membentuk dan menciptakan sebuah karya baru. 
Penelitian ini di lakukan tidak terlepas dari penelitia-penelitian terdahulu, hasil penelitian yang mempertegas penelitian ini adalah penelitian dari Yurike (2015) yang berjudul "Pengaruh Kertas Kokoru Terhadap Perkembangan Kreativitas Anak di Taman Kanak-kanak Karya Padang. Hasil penelitian menunjukkan bahwa penggunaan kertas kokoru memberi pengaruh yang signifikan terhadap perkembangan kreativitas anak di TK Karya Padang. Afriani (2016) pengaruh bermain finger painting terhadap kreativitas anak usia 5-6 tahun di raudhatul athfal (RA) akhlakul karimah kotabumi dengan jenis penelitian kuantitaif. Hasil penelitiannya dapat disimpulkan bahwa pengaruh bermain finger painting efektif digunakan terhadap kreativitas anak usia 5-6 tahun di raudhatul athfal (RA) akhlakul karimah kotabumi.

Adapun tujuan dari penelitian ini adalah untuk mengetahui seberapa besar pengaruh kreasi kertas kokoru terhadap kreativitas anak di Taman Kanak-kana Nurul Yakin Ringan-ringan Kabupaten Padang Pariaman

\section{METODE PENELITIAN}

Berdasarkan permasalahan yang diteliti yaitu "Pengaruh Kreasi Kertas Kokoru terhadap perkembangan kreativitas anak di TK Nurul Yakin Ringan-ringan Kabupaten Padang Pariaman", maka jenis penelitian ini adalah kuantitatif dengan metode Eksperimen dalam bentuk quasy experimen (Eksperimen semu). Menurut Sugiyono (2015:107) Metode eksperimen adalah penelitian yang digunakan untuk mencari pengaruh perlakuan tertentu terhadap yang lain dalam kondisi yang terkendalikan.

Populasi dalam penelitian ini adalah TK Nurul Yakin Ringan-ringan Kabupaten Padang Pariaman. TK Nurul Yakin Ringanringan Kabupaten Padang Pariaman memiliki 30 orang jumlah siswa yang terbagi dari dua kelompok belajar.
Kelompok belajar pertama adalah B1 dengan jumlah anak 15 orang. Kelompok belajar kedua adalah B2 dengan jumlah anak 15 orang.

Menurut Sugiyono (2012:118) "sampel adalah bagian dari jumlah dan karakteristik yang dimiliki oleh populasi tersebut". Arikunto (2012:174) mangatakan bahwa "sampel adalah bagian atau wakil populasi yang di teliti. Adapun teknik pengambilan sampel yang dilakukan dalam penelitian adalah teknik sampling jenuh. Menurut Sugiyono (2014:85) sampling jenuh adalah teknik pengumpulan sample bila semua anggota populasi digunakan sebagai sampel. Hal ini sering dilakukan bila jumlah populasi relatif kecil, kurang dari 30 orang, atau penelitian yang ingin membuat generalisasi dengan kesalahan yang sangat kecil. Istilah lain sampel jenuh adalah sensus, dimana semua anggota populasi dijadikan sampel.

Menurut Sugiyono (2015: 60) variabel adalah segala sesuatu yang berbentuk apa saja yang ditetapkan oleh peneliti untuk dipelajari sehingga diperoleh informasi tentang hal tersebut, kemudian ditarik kesimpulannya. Dalam penelitian ini terdapat dua variabel yaitu variabel bebas dan variabel terikat. Dimana variabel bebasnya yaitu perilaku yang diberikan kepada anak adalah dengan membuat kreasi kertas kokoru dan variabel terikatnya kemampuan kreativitas pada anak.

Teknik pengumpulan data yang digunakan dalam penelitian ini adalah tes buatan guru. Tes dikatakan valid apabila tes itu dapat mengukur apa yang hendak diukur. Instrumen ini menggunakan format checklist untuk penilaiannya. Dengan kriteria penilaian yaitu Berkembang Sangat Baik diberi skor 4, Berkembang Sesuai Harapan 3, Mulai Berkembang 2, Belum Berkembang 1.

Adapun teknik analisis data yang digunakan dalam penelitian ini adalah membandingkan perbedaan dari dua rata- 
rata nilai, sehingga dilakukan dengan uji t $(t$ tes). Namun sebelum itu terlebih dahulu melakukan uji normalitas dan uji homogenitas. Sebelum melakukan analisis perbedaan tersebut, perlu dilakukan uji normalitas dengan uji liliefors, dan uji homogenitas dengan uji bartlett. Jika sudah diketahui sebuah data berdistribusi normal dan bersifat homogen baru dilakukan analisis data sesuai dengan teknik analisis yang telah dilakukan yaitu dengan mencari perbandingan dengan menggunakan $t$-test.

\section{HASIL DAN PEMBAHASAN Hasil}

Data hasil pre-test Perkembangan Kreativitas anak dikelas eksperimen dan kelas kontrol diolah untuk menentukan uji normalitas. Pada uji normalitas ini digunakan uji Liliefors seperti yang dikemukakan pada teknik analisis data. Berdasarkan uji normalitas kelas eksperimen dan kelas kontrol diperoleh harga $L_{o}$ dan $L_{t}$ pada taraf nyata 0,05 untuk $\mathrm{N}=15$ seperti tabel 1 :

Tabel 1. Hasil Perhitungan Pengujian Liliefors Pretest Kelas Eksperimen dan Kelas Kontrol

\begin{tabular}{lllllll}
\hline No & Kelompok & $\mathrm{N}$ & $\mathrm{A}$ & Lo & Lt & $\begin{array}{l}\text { Ketera } \\
\text { ngan }\end{array}$ \\
\hline 1 & $\begin{array}{l}\text { Eksperime } \\
\mathrm{n}\end{array}$ & 15 & 0,05 & $\begin{array}{l}0,1 \\
3\end{array}$ & $\begin{array}{l}0,2 \\
20\end{array}$ & $\begin{array}{l}\text { Norm } \\
\text { al }\end{array}$ \\
\hline 2 & Kontrol & 15 & 0,05 & $\begin{array}{l}94 \\
3\end{array}$ & $\begin{array}{l}0,2 \\
20\end{array}$ & $\begin{array}{l}\text { Norm } \\
\text { al }\end{array}$ \\
\hline
\end{tabular}

Berdasarkan tabel 1 terlihat bahwa kelas eksperimen nilai $L_{\text {hitung }} \mathbf{0 , 1 3}$ lebih kecil dari $L_{\text {tabel }} \mathbf{0 , 2 2 0}$ untuk $\alpha_{0,05}$. Dengan demikian nilai kelas eksperimen berasal dari data yang berdistribusi normal. Untuk kelas kontrol diperoleh Lhitung0,1943 lebih kecil dari $L_{\text {tabel }} \mathbf{0 , 2 2 0}$ untuk $\alpha_{0,05}$. Ini berarti bahwa data kelas kontrol berasal dari data yang berdistribusi normal.
Pengujian persyaratan yang kedua adalah pengujian homogenitas dengan menggunakanuji Barlett. Pengujian ini bertujuan untuk mengetahui apakah data berasal dari kelompok yang homogen, antara kelas eksperimen dan kelas kontrol. Jika chi kuadrat hitung < chi kuadrat tabel berarti data berasal dari kelompok yang homogen.

Hasil perhitungannya dapat dilihat pada tabel 2:

Tabel 2 Hasil Perhitungan Uji Homogenitas Pre-test Kelas Eksperimen dan Kelas Kontrol

\begin{tabular}{lcccc}
\hline Kelas & A & $\chi^{2}$ hitung & $\chi^{2}$ & $\begin{array}{l}\text { Kesimp } \\
\text { ulan }\end{array}$ \\
\hline Eksperimen & 0,05 & 0,21664 & 3,841 & $\begin{array}{c}\text { Homoge } \\
\mathrm{n}\end{array}$ \\
\hline Kontrol & & & & \\
\hline
\end{tabular}

Dari Tabel 2 terlihat bahwa $\chi^{2}$ hitung kelas eksperimen dan kelas kontrol lebih kecil dari $\chi_{\text {tabel }}^{2}\left(\chi_{\text {hitung }}^{2}<\chi_{\text {tabel }}^{2}\right.$, berarti kelas eksperimen dan kelas kontrol memiliki varians yang homogen.

Setelah dilakukan uji normalitas dan uji homogenitas, diketahui bahwa kedua kelas sampel berdistribusi normal dan mempunyai varians homogen. Maka dapat dilanjutkan dengan pengujian hipotesis dengan menggunakan teknik t-tes, untuk mengetahui apakah terdapat perbedaan yang signifikan untuk kedua kelas. Apabila $t_{\text {hitung }}<t_{\text {tabel }}$ berarti tidak terdapat perbedaan yang signifikan antara kedua kelas.

Pada tabel 3 diperlihatkan pengolahan data dengan dengan t-test:

Tabel 3 Hasil Perhitungan Nilai Pre-test Kelas Eksperimen dan Kelas Kontrol

Aspek Kelompok Kelompok


Jurnal IImiah Potensia, 2019, Vol. 4 (2), 78-86

https://ejournal.unib.ac.id/index.php/potensia

e-issn: 2621-2382 p-issn: 2527-9270

\begin{tabular}{ccc}
\hline & Eksperimen & Kontrol \\
\hline $\mathrm{N}$ & 15 & 15 \\
\hline $\bar{X}$ & 59,16 & 57,91 \\
\hline $\mathrm{SD}^{2}$ & 56,55 & 52,99 \\
\hline
\end{tabular}

Untuk menguji hipotesis digunakan $t$ test. Dari hasil uji hipotesis dengan menggunakan $t$-test diperoleh hasil pada tabel 4

Tabel 4. Hasil Perhitungan Pre-test Pengujian dengan t-test

\begin{tabular}{|c|c|c|c|c|c|c|}
\hline No & $\begin{array}{l}\text { Kelo } \\
\text { mpok }\end{array}$ & $\mathrm{N}$ & $\begin{array}{c}\text { Hasil } \\
\text { Rata- } \\
\text { rata }\end{array}$ & thitung & $\begin{array}{c}t_{\text {tabel }} \\
\alpha \\
0,05\end{array}$ & $\begin{array}{c}\text { Keputu } \\
\text { san }\end{array}$ \\
\hline 1 & $\begin{array}{c}\text { Eksper } \\
\text { imen }\end{array}$ & 15 & 59,16 & \multirow[t]{2}{*}{0,448} & 2.048 & \multirow{2}{*}{$\begin{array}{c}\text { Terima } \\
\mathrm{H}_{\mathrm{o}}\end{array}$} \\
\hline 2 & $\begin{array}{c}\text { Kontr } \\
\text { ol }\end{array}$ & 15 & 57,91 & & 41 & \\
\hline
\end{tabular}

Dilihat pada tabel 4 dengan $\mathrm{dk}\left(\mathrm{N}_{1}-1\right)$ $+\left(\mathrm{N}_{2}-1\right)=28$. Dalam table df untuk taraf nyata $\alpha=0,05(5 \%)$ di dapat harga $t_{\text {tabel }}=$ 2.048411, jadi thitung lebih kecil dari pada $t_{\text {tabel }}(\mathbf{0}, \mathbf{4 4 8 8}<2.048411)$. Maka dapat dikatakan bahwa hipotesis $\mathrm{H}_{\mathrm{a}}$ ditolak atau $\mathrm{H}_{\mathrm{o}}$ diterima. Dapat disimpulkan bahwa tidak terdapat perbedaan yang signifikan antara hasil pre-test (kemampuan awal) anak di kelas eksperimen dan kelas control dalam Perkembangan Kreativitas anak.

Berdasarkan uji normalitas kelas eksperimen dan kelas kontrol diperoleh harga $L_{0}$ dan $L_{t}$ pada taraf nyata 0,05 untuk $\mathrm{N}=15$ seperti pada tabel 5 berikut:

Tabel 5. Hasil Perhitungan Pengujian Liliefors PosttestKelas Eksperimen danKelas Kontrol

\begin{tabular}{ccccccc}
\hline $\mathrm{N}$ & Kelompok & $\mathrm{N}$ & $\mathrm{A}$ & $\mathrm{L}_{0}$ & $\mathrm{~L}_{\mathrm{t}}$ & $\begin{array}{c}\text { Keteran } \\
\text { gan }\end{array}$ \\
\hline 1 & $\begin{array}{c}\text { Eksperime } \\
\mathrm{n}\end{array}$ & 15 & $\begin{array}{c}0,0 \\
5\end{array}$ & 0,1924 & 0,220 & Normal \\
\hline 2 & Kontrol & 15 & $\begin{array}{c}0,0 \\
5\end{array}$ & 0,1642 & 0,220 & Normal \\
\hline
\end{tabular}

Berdasarkan tabel 5 terlihat bahwa kelas eksperimen nilai Lhitung 0,192444 lebih kecil dari $L_{\text {tabel }} 0,220$ untuk $\alpha=0,05$. Dengan demikian nilai kelas eksperimen berasal dari data yang berdistribusi normal. Untuk kelas kontrol diperoleh $L_{\text {hitung }} 0,16422$ lebih kecil dari $L_{\text {tabel }} 0,220$ untuk $\alpha=0,05$. Ini berarti bahwa data kelas kontrol berasal dari data yang berdistribusi normal.

Pengujian persyaratan yang kedua adalah pengujian homogenitas dengan menggunakan uji Bartlett. Pengujian ini bertujuan untuk mengetahui apakah data berasal dari kelompok yang homogen, antara kelas eksperimen dan kelas kontrol. Jika chi kuadrat hitung < chi kuadrat tabel berarti data berasal dari kelompok yang homogen.

Hasil perhitungannya dapat dilihat dalam tabel 6 :

Tabel 6. Hasil Uji Homogenitas Post-test Kelas Eksperimen dan Kelas Kontrol

\begin{tabular}{lcccc}
\hline Kelompok & $\mathrm{A}$ & $\begin{array}{c}\chi^{2} \\
\text { hitung }\end{array}$ & $\begin{array}{c}\chi^{2} \\
\text { table }\end{array}$ & Kesimpulan \\
\cline { 1 - 4 } Eksperimen & 0,05 & 0,378 & 3,841 & Homogen \\
\cline { 1 - 3 } Kontrol & 0,378 & & \\
\hline
\end{tabular}

Dari Tabel 6 terlihat bahwa $\chi^{2}$ hitung kelas eksperimen dan kelas kontrol lebih kecil dari $\chi^{2}$ tabel ( $\chi^{2}$ hitung $<\chi^{2}$ tabel), berarti kelas eksperimen dan kelas kontrol memiliki varians yang homogen.

Setelah dilakukan uji normalitas dan uji homogenitas, diketahui bahwa kedua kelompok sampel berdistribusi normal dan mempunyai varians homogen. Maka dapat dilanjutkan dengan pengujian hipotesis dengan menggunakan teknik t-test. untuk mengetahui apakah terdapat perbedaan yang signifikan untuk kedua kelompok. Apabila thitung $<\mathrm{t}$ tabel berarti tidak terdapat perbedaan yang signifikan antara kedua kelas. Pada tabel 7 digambarkan pengolahan data dengan t-test: 
Jurnal IImiah Potensia, 2019, Vol. 4 (2), 78-86

https://ejournal.unib.ac.id/index.php/potensia

e-issn: 2621-2382 p-issn: 2527-9270

Tabel 7. Hasil Perhitungan Nilai Post-test Kelas

Eksperimen dan Kelas Kontrol

\begin{tabular}{ccc}
\hline Aspek & $\begin{array}{c}\text { Kelas } \\
\text { Eksperimen }\end{array}$ & $\begin{array}{c}\text { Kelas } \\
\text { Kontrol }\end{array}$ \\
\hline $\mathrm{N}$ & 15 & 15 \\
\hline $\bar{X}$ & 80 & 73,75 \\
\hline $\mathrm{SD}^{2}$ & 63,52 & 47,88 \\
\hline
\end{tabular}

Untuk menguji hipotesis digunakan ttest. Dari hasil uji hipotesis dengan menggunakan t-test diperoleh hasil yang tampilkan pada tabel 8 sebagai berikut:

Tabel 8. Hasil Perhitungan Post-test Pengujian dengan t-test

\begin{tabular}{ccccccc}
\hline No & Kelompok & N & $\begin{array}{c}\text { Hasil } \\
\text { Rata-rata }\end{array}$ & t hitung & $\begin{array}{c}\text { t tabel } \\
\alpha 0,05\end{array}$ & Keputusan \\
\hline 1 & Eksperimen & 15 & 80 & 2,22419 & 2.04841 & Tolak $\mathrm{H}_{\circ}$ \\
\hline 2 & Kontrol & 15 & 73,75 & & \\
\hline
\end{tabular}

Dilihat pada table 8 di atas dengan $\mathrm{dk}$ $(\mathrm{N} 1-1)+(\mathrm{N} 2-1)=28$. Dalam table df untuk taraf nyata a 0,05 di dapat harga ttabel2.048411, jadi thitung lebih besar dari pada $t_{\text {tabel }}(2,224199>2.048411)$. Maka dapat dikatakan bahwa hipotesis $\mathrm{H}_{\mathrm{a}}$ diterima atau $\mathrm{H}_{\mathrm{o}}$ ditolak. Dapat disimpulkan bahwa terdapat perbedaan yang signifikan antara hasil post-test (hasil akhir) anak di kelas eksperimen dan kelas control dalam pengembangan perkembangan kreativitas.

Setelah dilakukan perhitungan nilai pre-test dan post-test kelas eksperimen dan kontrol maka selanjutnya akan dilakukan perbandingan antara nilai pre-test dan nilai post-test, yang tujuannya untuk melihat apakah ada perbedaan nilai post-test dan nilai pre-test anak. Untuk itu lebih lengkapnya dapat dilihat di tabel 9 :

Tabel 9 Perbandingan Hasil Perhitungan Nilai Pre-test dan Nilai Post-test Variabel Pre-test Post-test

\begin{tabular}{ccccc} 
& Eksperimen & Kontrol & Eksperimen & Kontrol \\
\hline Nilai tertinggi & 68,75 & 68,75 & 80 & 73,75 \\
\hline Nilai terendah & 43,75 & 37,5 & 68,75 & 62,5 \\
\hline Rata-rata & 59,16 & 57,91 & 80 & 73,75 \\
\hline
\end{tabular}

Berdasarkan tabel 9 di atas, terlihat perbandingan hasil perhitungan nilai pretest dan nilai post-test. Pada pre-test nilai tertinggi yang diperoleh anak kelas eksperimen yaitu 68,755 dan nilai terendah 43,755 , dengan rata-rata 59,166 sedangkan pada kelas kontrol nilai tertinggi yang diperoleh anak yaitu 68,75 dan nilai terendah 37,55 dengan rata-rata 57,911.
Pada post-test nilai tertinggi yang diperoleh anak kelas eksperimen yaitu 1000 dan nilai terendah 68,755 dengan rata-rata 800, sedangkan pada kelas kontrol post-test nilai tertinggi yang diperoleh anak yaitu 78,55 dan nilai terendah 62,55 dengan rata-rata 73.755.

Perbandingan hasil perhitungan nilai pre-test dan post test terlihat pada nilai 
tertinggi dan nilai terendah yang diperoleh anak dan terlihat pada rata-rata kelas eksperimen dan kelas kontrol pada posttest dimana pada post-test rata-rata menjadi lebih efektif dari rata-rata pre-test setelah dilakukan treatment. Untuk lebih jelasnya dapat dilihat pada grafik pada gambar 1.

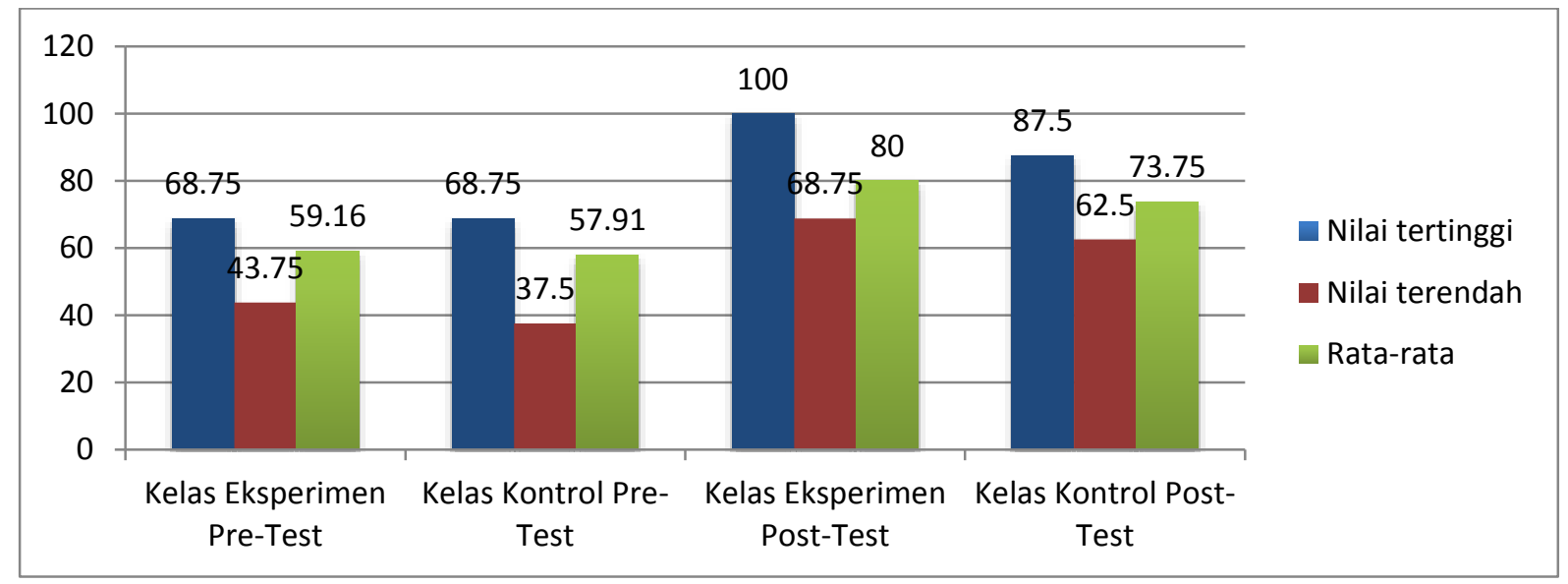

Gambar 1. Data Perbandingan Hasil Pre-test dan Post-test Perkembangan Kreativitas Anak Kelas Eksperimen dan Kelas Kontrol

Berdasarkan grafik di gambar 1 di atas dapat disimpukan bahwa perkembangan Kreativitas anak berpengaruh dengan Kreasi kertas Kokoru dibandingkan dengan Kertas warna, terlihat dari nilai pada rata-rata yang berhasil dicapai anak yaitu kelas eksperimen 80 sedangkan kontrol 73,755.

\section{Pembahasan}

Berdasarkan hasil pre-test Perkembangan Kreativitas anak pada kelas eksperimen dan kelas kontrol pada pre-test diperoleh angka rata-rata kelas eksperimen yaitu 59,166. Angka rata-rata kelompok kontrol yaitu 57,911. Berdasarkan hasil analisis data yang telah dilakukan bahwa thitung sebesar 0,448 dibandingkan dengan $\alpha 0,05\left(t_{\text {tabel }}=2,048411\right)$ dengan derajat kebebasan $\mathrm{dk}(\mathrm{N} 1-1)+(\mathrm{N} 2-1)=28$. Dengan demikian thitung $<t_{\text {tabel }}$ yaitu $0,448<$ 2,04841, maka dapat dikatakan bahwa hipotesis Ha ditolak atau Ho diterima.

Hasil Perkembangan Kreativitas anak pada kelas eksperimen dan kelas kontrol pada post-test diperoleh angka rata-rata kelompok eksperimen yaitu 80 . Angka ratarata kelas kontrol yaitu 73,75. Berdasarkan hasil analisis data yang telah dilakukan bahwa thitungsebesar 2,22419 dibandingkan dengan $\alpha 0,05 \quad\left(\mathrm{tt}_{\text {abel }}=\right.$ 2,04841 ) dengan derajat kebebasan dk (N1$1)+(N 2-1)=28$. Dengan demikian thitung $>$ ttabel yaitu 2,22419>2,04841, maka dapat dikatakan bahwa hipotesis $\mathrm{Ha}$ diterima atau $\mathrm{H}_{\mathrm{o}}$ ditolak. Jadi disimpulkan bahwa terdapat pengaruh yang signifikan dari Kreasi Kertas Kokoru terhadap Perkembangan Kreativitas anak di Taman Kanak-kanak Nurul Yakin Ringan-ringan Kabupaten Padang Pariaman. Karena dalam berkreasi dengan kertas kokoru ini guru mediakan alat dan bahan yang menarik dan bervariasi bagi anak. Hal ini sesuai dengan pendapat Latif (2014:156) mengatakan bahwa di dalam kegiatan pembelajaran, media yang digunakan guru harus menarik dan bervariasi sehingga anak tertarik untuk 
melakukan proses pembelajaran. Dengan adanya media kertas kokoru kegiatan yang diberikan kepada anak akan lebih menarik oleh anak.

Dalam penelitian ini, peneliti menggunakan beberapa item instrumen dalam kelas ekperimen dan kelas kontrol antara lain anak mampu menggabungkan gulungan kertas menjadi bentuk baru, Anak mampu membuat berbagai bentuk dari kertas, anak mampu mengkombinasikan warna kertas yang ingin di gunakan, anak mampu berkreasi dengan memberikan hiasan sesuai dengan imajinasi anak terhadap bentuk yang dibuat anak. Seluruh instrumen tersebut dilakukan dengan kegiatan yang menyenangkan dan tidak membosankan, karena dengan berkreasi dengan kertas kokoru akan membuat anak lebih tertarik karna teksturnya yang bergelumbang akan memudahkan anak dalam menggulung kertas tersebut di bandingkan dengan kertas warna yang tekturnya yang datar dan licin. Pada saat penelitian terlihat perbedaan antara kelas eksperimen dan kelas kontrol terkait dengan keantusiasan anak dalam pembelajaran, pada kelas eksperimen menggunakan kertas kokoru. Suryani (2014:10-11) kertas kokoru adalah kertas yang bergelombang yang dapat digunakan untuk mengembangkan kreativitas. Anakanak dapat mengasah kreativitas mereka, Anak dapat berimajinasi membentuk gulungan-gulungan dan menyatukan gulungan tersebut menjadi kreasi yang menarik.

Sedangkan pada kelompok kontrol yang dilakukan adalah berkreasi dengan kertas warna, sebagian besar anak kurang antusias untuk melakukan kegiatan. Anakanak kurang tertarik dengan media yang disediakan yaitu ketas warna yang bentuknya sama dengan kertas tulis biasa, anak tampak cepat bosan melakukan kegiatan dengan kertas warna ini.
Jadi, kreasi kertas kokoru ini sangat berpengaruh terhadap perkembangan kreativitas anak, dapat terlihat saat anak anak berkreasi dengan kertas kokoru, anak antusias dalam mengerjakan berbagai bentung binatang yang ingin ia buat dan menkombinasikan warna yang akan ia gunakan dalam membuat kreasi dengan kertas kokoru, anak juga dapat memberikan asesori-asesoris yang menarik untuk kreasi yang telah ia buat.

Hasil perkembangan kreativitas anak di kelas eksperimen lebih berpengaruh dari pada hasil perkembangan kreativitas anak di kelas kontol, dapat dilihat dari rata-rata nilai anak kelas eksperimen yang lebih tinggi dari pada kelas kontrol. Berdasarkan hal tersebut dapat di simpulkan bahwa terdapat perbedaan yang signifikan antara perkembangan kreativitas anak di kelas eksperimen dan kelompok kontrol menunjukan bahwa kreasi kertas kokoru berpengaruh terhadap perkembangan kreativitas anak.

\section{KESIMPULAN}

Berdasarkan hasil analisis data penelitian yang telah dilakukan, dapat diambil kesimpulan sebagai berikut: berdasarkan hasil uji hipotesis yang didapat yaitu $t_{\text {hitung }}>t_{\text {tabel }}$ dimana 2,224199> 2,048411 yang dibuktikan dengana taraf signifikan $\alpha=0,05$ dan $\mathrm{dk}=28$ ini berarti hipotesis $H_{a}$ diterima dan $H_{o}$ ditolak, dalam arti kata bahwa terdapat perbedaan yang signifikan antara hasil kemampuan Kreativitas anak yang menggunakan kertas kokoru di Taman Kank-kanak Nurul Yakin Ringan-ringan Kabupaten Padang Pariaman. Dengan demikian dapat disimpulkan bahwa Kreasi kertas kokoru berpengaruh terhadap kemampuan kreativitas anak di Taman Kanak-kanak Nurul Yakin Ringan-ringan Kabupaten Padang Pariaman.

\section{Saran}


Berdasarkan hasil penelitian yang mengemukakan saran sebagai berikut:

Bagi anak, diharapkan agar kemampuan kreativitas anak dapat berkembang dengan baik melalui kreasi kertas kokoru.

Bagi guru, dalam mengembangkan kemampuan kreativitas anak hendaknya guru merancang kegiatan dan menggunakan media yang bervariasi kepada anak. Melalui aktivitas yang menarik anak lebih mudah. Salah satu kegiatan pembelajaran yang dapat digunakan adalah berkreasi dengan kertas kokoru.

Bagi sekolah, dalam mengembangkan pembelajaran khususnya kemampuan kreativitas hendaknya sekolah dapat memberikan arahan dan motivasi serta dorongan kepada guru untuk menciptakan inovasi-inovasi baru dalam kegiatan pembelajaran untuk mengembangkan kemampuan kreativitas anak.

Bagi peneliti selanjutnya, diharapkan dapat meneliti dan menyampaikan gagasan tentang pembelajaran yang digunakan dalam kemampuan kreativitas anak serta menjadi inspirasi dalam melakukan penelitian dimasa yang akan datang.

\section{DAFTAR PUSTAKA}

Agustriana, N. (2013). Pengaruh Metode Edutainment Dan Konsep Diri Terhadap Keterampilan Sosial Anak. Jurnal Pendidikan Usia Dini, 7(2), 267-286.

Agustriana, N. (2019). PENGARUH METODE EDUTAINMENT DAN IDENTITAS DIRI TERHADAP KETERAMPILAN SOSIAL ANAK. Al-Fitrah, 1(2), 216-228. Retrieved from

http://ejournal.iainbengkulu.ac.id/inde x.php/alfitrah/article/view/1517

Amalia, K., Saparahayuningsih, S., \&
Suprapti, A. (2018).

MENINGKATKAN KEMAMPUAN

SAINS MENGENAL BENDA CAIR MELALUI METODE EKSPERIMEN.

Jurnal Ilmiah POTENSIA, 3(2).

https://doi.org/10.33369/jip.3.2

Arikunto, S. (2010). Prosedur Penelitian Suatu Pendekatan Praktis. Jakarta: PT Asdi Mahasarya

Budiwirman. (2012). Seni, Seni Grafis, dan Aplikasinya dalam Pendidikan. Padang: UNP PRESS

Depdiknas. (2003). Undang-undang No.20 Tahun 2003 tentang sistem pendidikan Nasional. Jakarta

Direktorat Pembinaan PAUD. (2015). Kerangka Dasar dan Struktur Kurikulum 2013 Pendidikan Anak Usia Dini. Jakarta: Direktorat Jenderal PAUD dan Masyarakat.

Husna, M., Pransiska, R., \& Yulsyofriend, Y. (2019). Pengaruh Kegiatan Origami Kertas Washi Terhadap Kreativitas Anak Di Taman Kanak-Kanak Aisyiah No. 1 Muara Panas Kabupaten Solok. Jurnal Ilmiah POTENSIA, 4(1), 67-77. https://doi.org/10.33369/jip.4.1.67-77

Indria, V. P., Sumarsih, S., \& Agustriana, N. (2017). Meningkatkan kemampuan Membaca Permulaan pada Anak Kelompok A PAUD Sambela Kota Bengkulu. Jurnal Ilmiah POTENSIA, 2(2), 95-100. https://doi.org/10.33369/JIP.2.2.95$\underline{100}$

Julianti, R., \& Nasirun, H. M. (2018). PELAKSANAAN PERILAKU HIDUP BERSIH DAN SEHAT (PHBS) DI LINGKUNGAN SEKOLAH. Jurnal Ilmiah Potensia (Vol. 3). Retrieved from 
https://ejournal.unib.ac.id/index.php/p otensia/article/view/2960/pdf

Kurniah, N., Andreswari, D., \& Kusumah, R. G. T. (2019). Achievement of Development on Early Childhood Based on National Education Standard. In Proceedings of the International Conference on Educational Sciences and Teacher Profession (ICETeP 2018) (pp. 351354). Paris, France: Atlantis Press. https://doi.org/10.2991/icetep18.2019 .82

Rachmawati, Y. dan Kurniati, E. (2010). Strategi Pengembangan Kreativitas Pada Anak Usia Taman KanakKanak. Jakarta : Kencana

Sumanto. (2005). Pengembangan kreativitas seni rupa anak TK. Jakarta.

Suryani, R. (2014). Kerajinan Kokoru Untuk Anak. Yogyakarta: Arcitra
Sugiyono. (2012). Metode Penelitian Administrasi. Bandung: Alfabeta

Sugiyono. (2015). Metode Penelitian Pendidikan Pendekatan Kuantitatif, Kualitatif, dan R \& D (cetakan ke 15). Bandung: Alfabeta.

Yulsyofriend. (2013). Permainan membaca dan menulis anak usia dini. Padang : Sukabina Press.

Wati, K. I., Saparahayuningsih, S., \& Yulidesni, Y. (2017). Meningkatan Keterampilan Motorik Halus Anak Melalui Kegiatan Pembelajaran Membatik Menggunakan Media Tepung Pada Anak Kelompok B PAUD Aisyiyah III Kota Bengkulu. Jurnal Ilmiah POTENSIA, 2(2), 9194. https://doi.org/10.33369/jip.2.2 